\title{
Isolation, screening, characterization, and identification of alkaline protease- producing bacteria from leather industry effluent
}

Chandran Masi ${ }^{1,2^{*}}$, Getachew Gemechu ${ }^{1}$ and Mesfin Tafesse ${ }^{1,2}$

\begin{abstract}
Background: A wide variety of bacterial species produces protease enzyme, and the application of the same enzyme has been manipulated precisely and used in various biotechnological areas including industrial and environmental sectors. The main aim of this research study was to isolate, screen, and identify alkaline proteaseproducing bacteria that were sampled from leather industry effluent present in the outer skirts of Addis Ababa, Ethiopia.

Purpose: To isolate and characterize the alkaline protease-producing bacteria from leather industrial effluents. Methods: Samples are collected from Modji leather industrial effluents and stored in the microbiology lab. After isolated bacteria from effluent using serial dilution and followed by isolated protease-producing bacteria using skim milk agar media. After studying primary and secondary screening using zonal inhibition methods to select potential protease-producing bacteria using skim milk agar media. Finally, to identify the potential bacteria using biochemical methods, bacterial biomass, protease activity, and gene sequencing (16S rRNA) method to finalize the best alkaline protease producing bacteria identified.

\footnotetext{
* Correspondence: biochandran1976@gmail.com

${ }^{1}$ Department of Biotechnology, College of Biological and Chemical

Engineering, Addis Ababa Science and Technology University, Addis Ababa, Ethiopia

${ }^{2}$ Center of Excellence, Bioprocess and Biotechnology, Addis Ababa Science and Technology University, Addis Ababa, Ethiopia
}

(c) The Author(s). 2021 Open Access This article is licensed under a Creative Commons Attribution 4.0 International License, which permits use, sharing, adaptation, distribution and reproduction in any medium or format, as long as you give appropriate credit to the original author(s) and the source, provide a link to the Creative Commons licence, and indicate if changes were made. The images or other third party material in this article are included in the article's Creative Commons licence, unless indicated otherwise in a credit line to the material. If material is not included in the article's Creative Commons licence and your intended use is not permitted by statutory regulation or exceeds the permitted use, you will need to obtain permission directly from the copyright holder. To view a copy of this licence, visit http://creativecommons.org/licenses/by/4.0/ 
(Continued from previous page)

Results: First twenty-eight different bacterial colonies were isolated initially from the leather industry effluent sample situated at the Modjo town of Ethiopia. The isolated bacteria were screened using the primary and secondary screening method with skim milk agar medium. At the primary level, we selected three isolates namely ML5(14 mm), ML12(18 mm), and MS12 $(15 \mathrm{~mm})$, showing the highest zone of proteolysis as a result of casein degradation on the agar plates were selected and subjected to primary screening. Further secondary screening

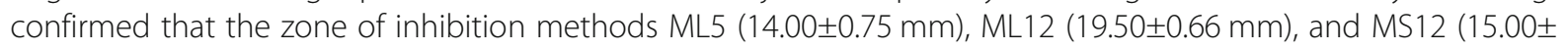
$1.32 \mathrm{~mm}$ ) has efficient proteolytic activity and can be considered as effective protease producer. The three isolates were then subjected to morphological and biochemical tests to identify probably bacterial species, and all the three bacterial isolates were found out to be of Bacillus species. The shake flask method was carried out to identify the most potent one having greater biomass production capabilities and protease activity. ML12 isolated from leather effluent waste showed the highest protease activity $(19 \mathrm{U} / \mathrm{ml})$, high biomass production, and the same was subjected to molecular identification using 16 s sequencing and a phylogenetic tree was constructed to identify the closest neighbor. The isolate ML12 (Bacillus cereus strain -MN629232.1) is 97.87\% homologous to Bacillus cereus strain (KY995152.1) and 97.86\% homologous to Bacillus cereus strain (MK968813.1).

Conclusions: This study has exposed that from twenty-eight different bacterial samples isolated from leather industry effluent; further primary and secondary screening methods were selected three potential alkaline protease strains. Finally, based on its biochemical identification, biomass, and protease activity, ML12 (Bacillus cereus strains) is the best strain identified. The alkaline protease has the significant feature of housing potent bacterial species for producing protease of commercial value.

Keywords: Protease, Leather industry effluents, Skim milk agar, Casein, Bacterial screening

\section{Background}

Cells of every living organism consist of a chemical substance that possesses the ability to catalyze or speed up a biochemical reaction and acts as biocatalysts, which are known as enzymes. Enzymes have better catalytic efficiency, adjustable activity, and high specificity when compared to catalysts of chemical or synthetic origin. These advantages have broadened the application of enzymes in various industries such as chemical, food, and pharmaceutical (Pires-Cabral et al. 2010; Yucel 2012; Masi et al. 2017a). This has generated a greater demand for enzyme production of high quality by cost-effective and commercial methods. Due to its importance, almost every form of life on earth possesses alkaline protease enzymes as an important factor in their physiological function. Though the protease enzymes are produced by different forms of life, due to their flexibility towards genetic manipulation, the ones that are produced by microbial sources such as bacteria and fungi are more preferred rather than human or plant protease enzymes (Masi et al. 2014; Tiwari et al. 2015).

Proteases are considered the most useful and powerful enzymes as they break down complex protein compounds into amino acids and peptides (Gupta et al. 2002; Verma et al. 2011; Masi et al. 2015). Around 60\% of global enzyme usage is accounted for by protease enzymes. Alkaline proteases are the most industrially used or exploited enzymes. Prominent bacterial producers of this enzyme are Pseudomonas sp., Bacillus sp., Staphylococcus sp., and Aeromonas sp. (Saha et al. 2011; Masi et al. 2017b). Being one among the most widely used enzyme, comparatively, protease holds a larger scope for the research and commercialization of any other type of enzyme.

There is a need to develop novel protease enzymes for further necessary applications of these enzymes. Moreover, enzymes produced by bacteria that are present in effluents are a greater boon to establishing the significance of converting industrial wastes to highly valuable enzymes especially like proteases (Tiwari et al. 2015; Masi 2020). The main purpose of this study is isolation, screening, and identification by morphological and biochemical aspects of potent alkaline protease-producing bacteria from leather industry effluent.

\section{Methods \\ Materials}

Chemicals, reagents, and culture mediums necessary for the experiment, e.g., skimmed milk agar, Luria Bertani agar, casein, nutrients agar, saffron, phenol red, urea, starch, sodium chloride, magnesium sulfate, magnesiumnitrate, glucose, calcium chloride, hydrogen peroxide, peptone, and Folin's reagent. All these purchases are made by Himedia Laboratories Pvt Ltd and Biobasic Company.

\section{Description of the sampling area}

This research work was conducted in Modjo town, which is located in the East Oromia regional state of Ethiopia. The geographical coordinates of the town are 
$8^{\circ} 35^{\prime} \mathrm{N}$ and $39^{\circ} 07^{\prime} \mathrm{E}$. Its elevation above sea level is seen between 1788 and $1825 \mathrm{~m}$. The town harbors Modjo tanning industry is located $80 \mathrm{~km}$ south of Addis Ababa. The Modjo Tanning Industry is an average-sized leather industry. It has a goat and sheepskin processing unit with a capacity of 844,000 to $1,656,000$ skins that can be processed annually. Effluent waste of 3500-5500 cubic meters per day from the Modjo Tanning industry is channeled towards the Modjo River (Reda 2016).

\section{Source of sample collection}

Soil samples designated as MS and water effluents which were designated as ML are collected from different areas of the Modjo leather industry. Soil samples from the mentioned site were collected from the wastes of hides and skin. Effluent samples are collected from the site where the effluents are pumped out from the Modjo Tanning Industry. The soil samples were taken in sterile plastic bags and the water sample was taken in a sterile bottle. Both samples were taken to the Microbiology laboratory at Addis Ababa Science and Technology University, Ethiopia. The samples are stored at $4{ }^{\circ} \mathrm{C}$ for further steps.

\section{Isolation of bacteria from the leather effluent}

The serial dilution technique was carried out to reduce the microbial load. Nine milliliters of normal saline was prepared in 9 test tubes and $1 \mathrm{ml}$ of the effluent sample was added to the first tube which has a dilution of $10^{-1}$ and serially diluted up to $10^{-9}$ dilution. The same procedure was carried out for the soil sample where 1 gram of collected soil was added to the first tube and serially diluted up to $10^{-9}$ dilution. Serial dilution and spread plate methods were the techniques used to isolate the target bacteria. As the bacterial sample is the targeted microorganism, the dilution $10^{-5}$ is used for further tests. Four grams of Luria Bertani agar medium ( $1 \mathrm{~g}$ peptone, $0.5 \mathrm{~g}$ yeast extract, and $0.5 \mathrm{~g} \mathrm{NaCl}$ for $100 \mathrm{ml}$ ) and add $4 \mathrm{~g}$ of agar with $100 \mathrm{ml}$ of distilled water, with maintaining $\mathrm{pH}$ is 8.5 was prepared and sterilized by autoclave and poured onto the Petri plates. Spread plating technique is carried out for the growth of bacterial consortium by adding $0.1 \mathrm{ml}$ of the $10^{-5}$ diluted sample and spread using L-rod. The agar plates were then incubated at $30{ }^{\circ} \mathrm{C}$ for $24 \mathrm{~h}$ and observed for microbial growth. Consortiums of bacteria showing various colony morphology were observed in the plates. Similar colonies were considered to be the same bacteria whereas; different colony morphology is exhibited by different microorganisms. Thus, the distinct colonies are then isolated to obtain pure colonies by the streak plate method. The same LB agar medium was prepared and sterilized and then streaked with each distinct colony by quadrant streaking. The plates are incubated at $30{ }^{\circ} \mathrm{C}$ for $24 \mathrm{~h}$ and then observed to isolated pure colonies of bacteria obtained from the leather industrial waste site (Sneha et al. 2014).

\section{Screening of bacterial isolates for alkaline protease production \\ Primary screening of potential alkaline protease-producing bacterial isolates}

Primary screening of bacterial isolates was made to screen alkaline protease producers using 1\% skim milk agar (skin milk powder $2.8 \mathrm{~g}$, casinenzymic hydrolysates $500 \mathrm{mg}$, yeast extract $250 \mathrm{mg}$, dextrose $100 \mathrm{mg}$, and agar $1.5 \mathrm{~g}$ ) power with $100 \mathrm{ml}$ of distilled water maintaining $\mathrm{pH} 8.5$ by spot inoculation of the isolates using $2 \mathrm{~mm}$ toothpick heads and were incubated at room temperature. A clearance zone around the inoculated site as a result of proteolytic activity was observed for 3 days. Isolates seen with a clearance zone of more than $10 \mathrm{~mm}$ were selected and proceeded for secondary screening (Masi et al. 2014).

\section{Secondary screening of potential alkaline protease- producing bacteria}

Selected bacterial isolates from primary screening were grown in a $1 \mathrm{~g}$ of Nutrient broth medium (beef extract $0.1 \mathrm{~g}$, yeast extract $0.2 \mathrm{~g}$, peptone $0.5 \mathrm{~g}$, and $\mathrm{NaCl} 0.5 \mathrm{~g}$ for $100 \mathrm{ml}$ ) with $100 \mathrm{ml}$ of distilled water at $\mathrm{pH} 8.5$ maintain. Then, $1 \%$ of the grown cultures were again inoculated in a freshly prepared nutrient broth medium and incubated in a rotary shaker for 2 days at room temperature. Post-incubation, centrifugation of the cultures was carried out at 10,000 RPM for $15 \mathrm{~min}$ at $4{ }^{\circ} \mathrm{C}$ and the supernatant is collected. $1 \%$ skim milk agar plates (skin milk powder $2.8 \mathrm{~g}$, casinenzymic hydrolysates $500 \mathrm{mg}$, yeast extract $250 \mathrm{mg}$, dextrose $100 \mathrm{mg}$, and agar $1.5 \mathrm{~g}$ with maintaining $\mathrm{pH} 8.5$ ) were prepared and wells were punched using a sterile cork borer of $9 \mathrm{~mm}$. Agar plates with $1 \%$ skim milk agar and add to $4 \%$ agar power with maintaining $\mathrm{pH} 8.5$ are prepared and sterilized and inoculated with. Twenty-five microliters of the collected supernatant of all the selected bacteria and then incubated at $30{ }^{\circ} \mathrm{C}$ for 2 days. The plates were observed for the zone of proteolysis around the inoculated wells. The enzymes which show a high zone of hydrolysis are selected and cultured in nutrient broth medium and also preserved in agar slants at $4{ }^{\circ} \mathrm{C}$ for further studies (Sneha et al. 2014, Masi et al. 2017a).

\section{Identification the best bacterial isolates}

Colonies that showed efficient proteolytic activity in secondary screening are then subjected to bacterial identification studies such as morphological and biochemical tests as demonstrated by Sharmin et al. (2005) which is modified from Bergey's Manual of Determinative Microbiology to find the probable bacteria. 


\section{Morphological characterization of bacterial isolates}

Colony characters of all the isolates are observed based on the bacterial growth on nutrient agar plates. Microscopy-based morphological studies including Gram staining, motility test, and endospore staining was done (Masi et al. 2014).

Colony characters The selected isolates were inoculated on nutrient agar plates by pour plate method and incubated at $30{ }^{\circ} \mathrm{C}$ for $24 \mathrm{~h}$ and observed for colony characters such as color, shape, surface, and opacity.

Motility test The preserved agar slants of the isolates are taken and inoculated in a cover glass using an inoculating needle. The cover glass is affixed on a concavity slide and focused under $\times 45$ objective to observe the presence or absence of motile rods (Legesse et al. 2017).

Gram staining After preparing a 24-h-old culture, it was smeared on the slide following fixing it with heat. it was treated with crystal violet for 2 min following rinsing with running water. It was again flooded with gram iodine solution for 2 min following washing it with alcohol. On the last, it was flooded with safranin, washed with water, dried, and observed under oil immersion (Harley and Prescott 2002).

Endospore staining This staining was done by heat fixing the smear on the microscopic slide. Malachite green was used to show the endospore. The slide was kept in the hot beaker for $5 \mathrm{~min}$. Safranin was added and washed away. it was observed under an electronic microscope (Bergey et al. 1994).

\section{Biochemical characterization of isolates}

Catalase test Hydrogen peroxide of 3\% was used to detect catalase taste. An overnight culture cell was mixed with hydrogen peroxide on the microscopic slide with the help of a sterilized loop. The formation of the bubble during and after mixing was recorded as a positive result (Boominadhan et al. 2009).

Starch hydrolysis The starch hydrolysis test was done by streaking the culture on the starch agar plate using an inoculating loop. After labeling the Petri plate and control, it was incubated at $30{ }^{\circ} \mathrm{C}$ after $24 \mathrm{~h}$ and observed for the zone of hydrolysis of starch using a $1 \%$ iodine solution (Harley and Prescott 2002).

Gelatin hydrolysis Preparation and sterilization of gelatin media as agar deep tubes were done using an autoclave. Stab inoculation of each isolate on the prepared gelatin media was done using an inoculation loop. The inoculated tubes are then subjected to incubation at 30
${ }^{\circ} \mathrm{C}$ for $48 \mathrm{~h}$ and then placed in a refrigerator for $15 \mathrm{~min}$ at $4{ }^{\circ} \mathrm{C}$ to observe gelatin liquefaction (Alnahdi 2012).

Urea hydrolysis test The broth of the urea agar medium was prepared and inoculated with isolated bacteria. Both test and control tubes were incubated at $37^{\circ} \mathrm{C}$. The slant was observed for color changes every 6 $\mathrm{h}$, and then for every $24 \mathrm{~h}$ for up to 5 days. Phenol red was used as an indicator (Harley and Prescott 2002).

Indole production test The peptone broth medium was prepared and autoclaved. After cooling the medium, it was inoculated and incubated at $30{ }^{\circ} \mathrm{C}$ for $48 \mathrm{~h}$ by keeping the control. Few drops of Kovac's reagent were added step by step. The tubes were shaken and allowed to stand for $10 \mathrm{~min}$, to form the layer. The presence of red-colored on the top of the tube is indicative of a positive result (Kiran et al. 2002).

Citrate utilization test Preparation and sterilization of Simmons citrate agar tube are done and inoculation of all the isolates by the process of stab inoculation and incubated at $37{ }^{\circ} \mathrm{C}$ for 24 hours. A positive result is indicated by the color change from green to intense Prussian blue color (Pandian et al. 2012).

Carbohydrate fermentation test A Carbohydrate fermentation test using various carbohydrates such as glucose, sucrose, lactose, and mannitol, and galactose was carried out for the selected isolates in an anaerobic condition. The nutrient broth which is incorporated with any one of the abovementioned carbohydrates along with a $\mathrm{pH}$ indicator phenol red which is red at $\mathrm{pH} 7$ (neutral) and yellow at a pH of 6.8 (acidic) is used as the medium for carbohydrate fermentation test. This specified carbohydrate-containing media is taken and inoculated with the isolates and Durham tubes are placed inside in an inverted position. The media is incubated in an anaerobic condition for $24 \mathrm{~h}$ at $30^{\circ} \mathrm{C}$. Fermentation of carbohydrates results in the formation of organic acids which changes the color of the media from pink to yellow, along with the liberation of gases which is entrapped in the Durham tubes (Harley and Prescott 2002; Agrahari and Wadhwa 2010).

Methyl red test Sterile MR-VP broth tubes were prepared and inoculated with the selected isolates and incubated at a temperature of $30{ }^{\circ} \mathrm{C}$ for 2 days. Post-incubation, the tubes were added with 5 drops of methyl red and were observed for any color change. A positive result is indicated by the color change from yellow to red after the addition of methyl red within 10 to $15 \mathrm{~s}$ (Mazotto et al. 2010).

Voges-Proskauer test Glucose phosphate broth (VogesProskauer) broth was autoclaved and cooled to room temperature. The 24-h cultures of the selected isolates were 


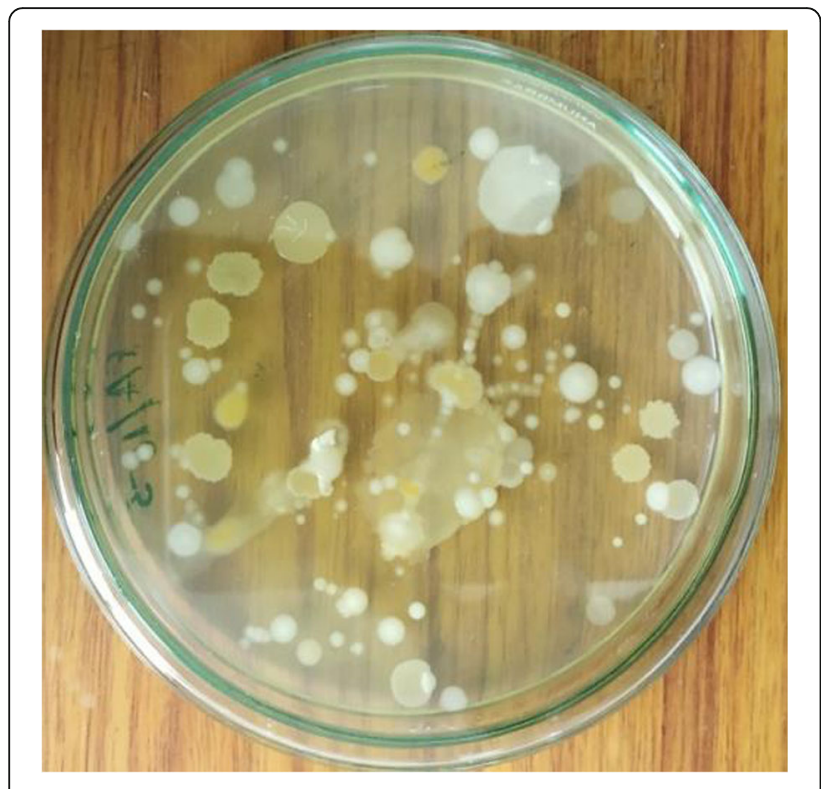

Fig. 1 Bacterial Isolation by spread plate technique

inoculated using a sterilized loop followed by incubation at $30{ }^{\circ} \mathrm{C}$ for $48 \mathrm{~h}$. Post-incubation, $1 \mathrm{ml}$ alpha-naphthol was added and shaken then followed by the addition of $0.5 \mathrm{ml}$ of $40 \% \mathrm{KOH}$ to the broth and shaken. Red color development after the addition of the reagents within $1 \mathrm{~h}$ was taken as a positive result (Han et al. 2012).

Triple sugar iron test (TSI) Bacterial gas production can be observed using triple sugar iron (TSI) agar slants. The TSI agar consists of a dye that is $\mathrm{pH}$ sensitive known as phenol red along with $1 \%$ of three sugars namely lactose, sucrose, and glucose, and then sodium thiosulfate, ferrous sulfate, and finally agar (Harley and Prescott 2002; Sharma 2007). A positive result is indicated by the blackening of the agar slants as a result of $\mathrm{H}_{2} \mathrm{~S}$ production.

\section{Shake flask studies for the screening of isolates}

The selected isolates from secondary screening are subjected to a shake flask study which is done following the protocol of Khan et al. (2011) with some modifications. Alkaline Protease production media (tryptone 1\%, yeast extract $0.5 \%$, skim milk $1 \%$, and $\mathrm{NaCl} 0.5 \%$ in the $\mathrm{pH} 8.5$ ) of $100 \mathrm{ml}$ is prepared and sterilized using autoclaved. A loop full of the culture from fresh slants of isolates selected by secondary screening was taken and inoculated in the sterilized media and incubated in a rotary shaker at 250 RPM for $48 \mathrm{~h}$ at $30{ }^{\circ} \mathrm{C}$. The biomass production of all the selected isolates was analyzed using a Visible Spectrophotometer at $660 \mathrm{~nm}$ absorbance to calculate the bacteria biomass.

\section{Determination of protease activity}

The universal protease assay with casein as a substrate will be followed to determine the protease activity of the potential protease-producing bacterial strains. One $\mathrm{ml}$ of potential alkaline protease producing bacterial sample will take after $48 \mathrm{~h}$ of incubation with nutrient broth medium with $\mathrm{pH} 8.5$ and centrifuged at $10,000 \mathrm{rpm}$ for $15 \mathrm{~min}$ at 4 ${ }^{\circ} \mathrm{C}$. The tyrosine standard curve will be obtained from the absorbance of the tyrosine concentrations (10, 20, 30, 40, 50 , and $60 \mu \mathrm{g}$ ) to determine the protease activity.

\section{Molecular identification of the selected isolate}

The isolate having the highest biomass, and alkaline protease production in the shake flask study was identified using the molecular technique. The genomic DNA of the isolate was extracted by using the Bacterial Genomic DNA extraction kit according to the manufacturer protocol (QIAGEN, QIAamp DNA Mini Kit) with some modification. The isolated DNA was then amplified using the following PCR mix: $1 \mu \mathrm{l}$ of bacterial universal 16S rRNA primers forward E9F (5-GAGT TTGATCCTGGCTCAG-3) (Farrelly et al. 1995) and $1 \mu \mathrm{l}$ of reverse primer U1510R (5-GGTTACCTTGTTACGACTT-3) (Reysenbach et al. 1995), $2 \mu \mathrm{l}$ of genomic DNA and $6 \mu \mathrm{l}$ of PCR grade water were added and the PCR amplification was done. Amplified sequence threads were submitted to the NCBI database and NCBI BLAST (http://www.ncbi.nlm.nih. gov/Blast) was carried out to distinguish the nearest neighbors of the isolates and then a phylogenetic tree was constructed.
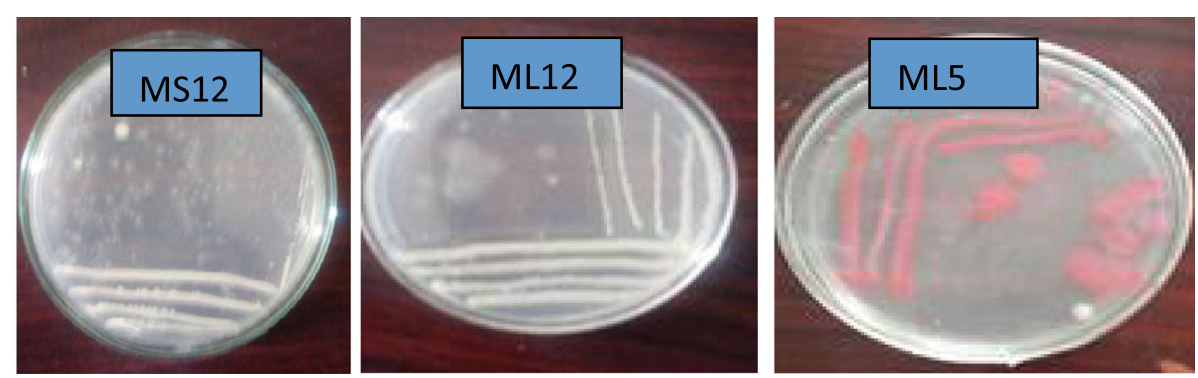

Fig. 2 Single colony isolation by streak plate technique 
Table 1 Primary screening of protease producing bacterial isolates

\begin{tabular}{|c|c|c|c|c|c|}
\hline S.No. & Isolate code & Zone of lysis & S.No. & Isolate code & Zone of lysis \\
\hline 1. & MS1 & $12 \mathrm{~mm}$ & 15. & MS15 & $8 \mathrm{~mm}$ \\
\hline 2. & MS2 & $8 \mathrm{~mm}$ & 16. & MS16 & $9 \mathrm{~mm}$ \\
\hline 3. & MS3 & $8 \mathrm{~mm}$ & 17. & ML1 & $7 \mathrm{~mm}$ \\
\hline 4. & MS4 & $7 \mathrm{~mm}$ & 18. & ML2 & $9 \mathrm{~mm}$ \\
\hline 5. & MS5 & $9 \mathrm{~mm}$ & 19. & ML3 & $11 \mathrm{~mm}$ \\
\hline 6. & MS6 & $9 \mathrm{~mm}$ & 20. & ML4 & $9 \mathrm{~mm}$ \\
\hline 7. & MS7 & $8 \mathrm{~mm}$ & 21. & ML5 & $14 \mathrm{~mm}$ \\
\hline 8. & MS8 & $13 \mathrm{~mm}$ & 22. & ML6 & $9 \mathrm{~mm}$ \\
\hline 9. & MS9 & $7 \mathrm{~mm}$ & 23. & ML7 & $13 \mathrm{~mm}$ \\
\hline 10. & MS10 & $6 \mathrm{~mm}$ & 24. & ML8 & $13 \mathrm{~mm}$ \\
\hline 11. & MS11 & $8 \mathrm{~mm}$ & 25. & ML9 & $9 \mathrm{~mm}$ \\
\hline 12. & MS12 & $15 \mathrm{~mm}$ & 26. & ML10 & $10 \mathrm{~mm}$ \\
\hline 13. & MS13 & $8 \mathrm{~mm}$ & 27. & ML11 & $6 \mathrm{~mm}$ \\
\hline 14. & MS14 & $10 \mathrm{~mm}$ & 28. & ML12 & $18 \mathrm{~mm}$ \\
\hline
\end{tabular}

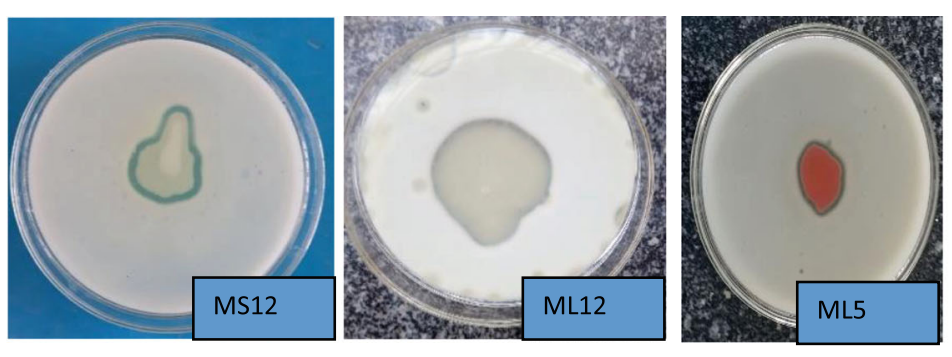

a. Primary Screening of Protease producing bacterial isolates
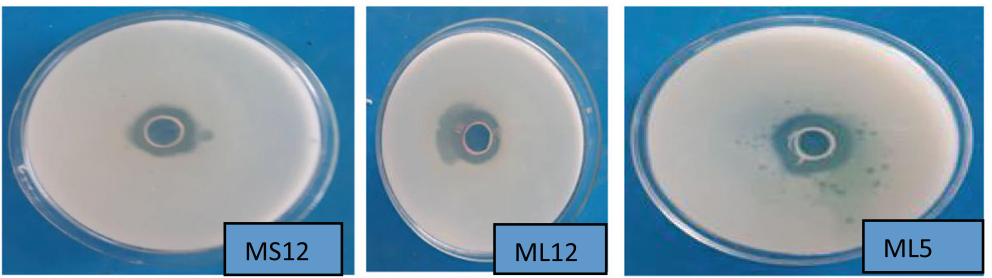

b. Secondary Screening of Alkaline protease producing bacterial isolates

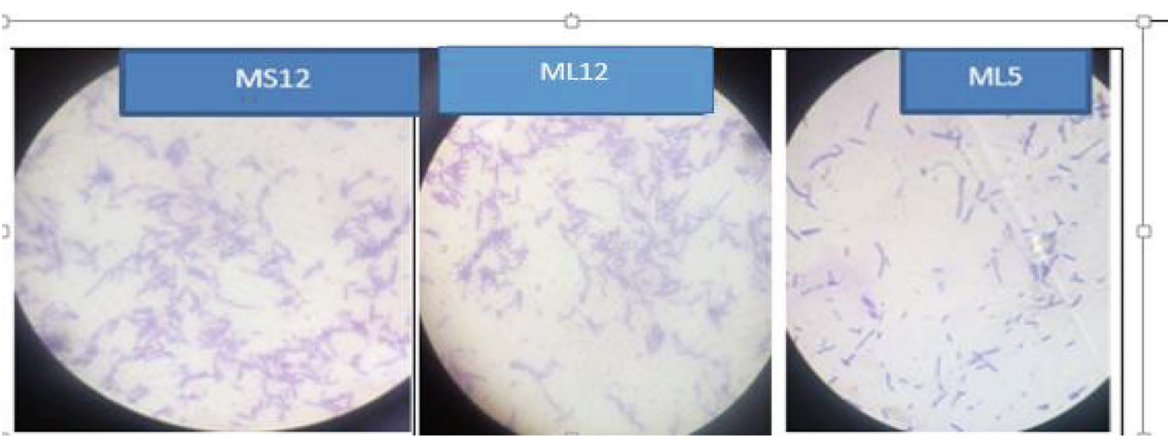

c. Gram Staining of Selected Alkaline protease producing bacterial isolates

Fig. 3 a Primary screening of protease producing bacterial isolates. b Secondary screening of alkaline protease producing bacterial isolates. c Gram staining of selected alkaline protease-producing bacterial isolates 


\section{Results}

Alkaline protease isolation from leather industry effluent bacteria

Bacteria from the leather industrial effluent site were subjected to serial dilution and then preceded for pour plating method in LB media to observe bacterial consortium. Based on colony morphology, each distinct morphological character was considered as different bacterial species and was subjected to the streak plate method for pure colony isolation and as shown in Figs. 1 and 2. A total of 28 different protease-producing bacterial isolates were isolated from the leather industry effluent sample. The isolates were subcultured and maintained in LB media for future tests.

\section{Primary and secondary screening of potential alkaline protease-producing bacterial isolates}

All the 28 isolates were subjected to primary screening for the process of identification of potential proteaseproducing species. The primary screening of potential protease-producing bacteria is indicated in Table 1 and Fig. 3a. Further, three distinct isolates namely ML5, ML12, and MS12 having the highest zones of inhibition were selected for secondary screening, and the results are tabulated in Table 2 and shown in Fig. $3 \mathrm{~b}$.

\section{Identification of screened bacterial isolates}

The three selected bacterial isolates namely ML5, ML12, and MS12 were grown on a nutrient agar medium to study its morphological characteristics. ML5 and MS12 isolates showed creamy red colonies, whereas ML12 showed white colonies. The colonies of all three isolates were smooth and opaque. Gram staining results revealed that all three isolates are motile rods possessing endospores where ML5, MS12, and ML12 are gram-positive. Morphological characteristics of the three isolates are tabulated in Table 3 and the gram staining results were shown in Fig. 3c.

An extensive biochemical characterization of all three isolates was carried out and is tabulated in Table 3. Results of the carbohydrate fermentation test revealed that all three isolates ferment sucrose hydrolysis, glucose hydrolysis, and galactose hydrolysis. Lactose is fermented only by the isolate ML5 whereas, Fructose is fermented by MS12 and ML12 and finally, mannitol is fermented by MS12 and MS5. All three isolates show positive for hydrolysis of starch and casein and liquefy gelatin. IMViC test shows that ML12 and ML5 were positive for the methyl-red test, MS12 and ML5

Table 2 Secondary screening of alkaline protease-producing bacterial isolates using zone of inhibition methods

\begin{tabular}{lll}
\hline S.No. & Isolate code & Diameter (in $\mathbf{~ m m})$ \\
\hline 1. & ML5 & $14.00 \pm 0.75$ \\
2. & ML12 & $19.50 \pm 0.66$ \\
3. & MS12 & $15.00 \pm 1.32$ \\
\hline
\end{tabular}

Table 3 Morphological and biochemical characterization of isolates

\begin{tabular}{|c|c|c|c|}
\hline \multirow[t]{2}{*}{ Characteristic } & \multicolumn{3}{|c|}{ Bacterial isolates } \\
\hline & ML5 & ML12 & MS12 \\
\hline \multicolumn{4}{|l|}{ Morphological features } \\
\hline Color & Creamy red & White & Creamy red \\
\hline Shape & Rod & Rod & Long Rod \\
\hline Surface & Smooth & Smooth & Smooth \\
\hline Opacity & Opaque & Opaque & Opaque \\
\hline Gram staining & Positive & Positive & Positive \\
\hline Motility & Motile & Motile & Motile \\
\hline Endospore staining & Positive & Positive & Positive \\
\hline \multicolumn{4}{|c|}{ Biochemical characteristic } \\
\hline Sucrose hydrolysis & Positive & Positive & Positive \\
\hline Lactose hydrolysis & Negative & Negative & Positive \\
\hline Glucose hydrolysis & Positive & Positive & Positive \\
\hline Fructose hydrolysis & Positive & Positive & Negative \\
\hline Mannitol hydrolysis & Positive & Negative & Positive \\
\hline Starch hydrolysis & Positive & Positive & Positive \\
\hline Galactose hydrolysis & Positive & Positive & Positive \\
\hline Indole test & Negative & Negative & Negative \\
\hline Methyl red test & Negative & Positive & Positive \\
\hline Urease test & Negative & Negative & Positive \\
\hline Voges-Proskauer test & Positive & Negative & Positive \\
\hline Casein hydrolysis & Positive & Positive & Positive \\
\hline Citrate utilization test & Positive & Negative & Negative \\
\hline Gelatin hydrolysis & Positive & Positive & Positive \\
\hline Catalase test & Positive & Positive & Positive \\
\hline Similarity of bacteria & Bacillus sp. & Bacillus sp. & Bacillus sp. \\
\hline
\end{tabular}

showed positive results for the Voges-Proskauer test, and MS12 showed positive for citrate utilization test. The isolate ML5 showed positive for urease whereas all the three isolates showed positive for the catalase test.

\section{Shake flask results for third screening of best alkaline protease-producing bacteria}

Three bacterial isolates that were subjected to secondary screening were selected for quantification of its bacterial biomass, and protease activity using the spectrophotometric method. Protease activity and bacterial biomass of the selected isolates were measured using the shake flask method by incubating the isolates on protease production media. The biomasses of each isolate and protease activity were measured by spectrophotometer at $660 \mathrm{~nm}$ by using casein as a substrate and their results are shown in Fig. 4a, b. Out of the three isolates studied, ML12 showed the highest intensity of absorbance proving biomass, and protease activity $(19 \mathrm{U} / \mathrm{ml})$ to be 


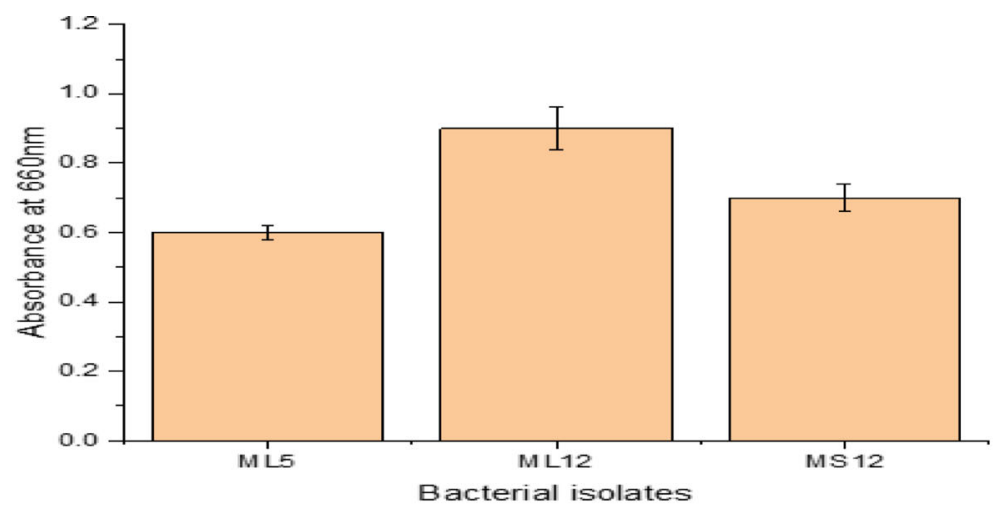

a. Biomass Production by Selected Alkaline protease producing bacterial isolates

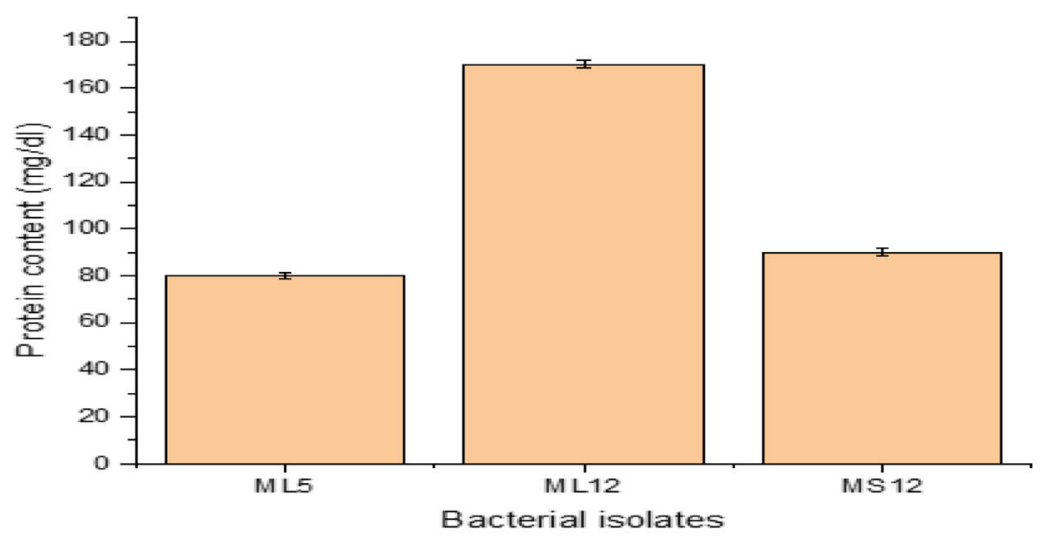

b. Total Protein Concentration of the selected bacterial isolates

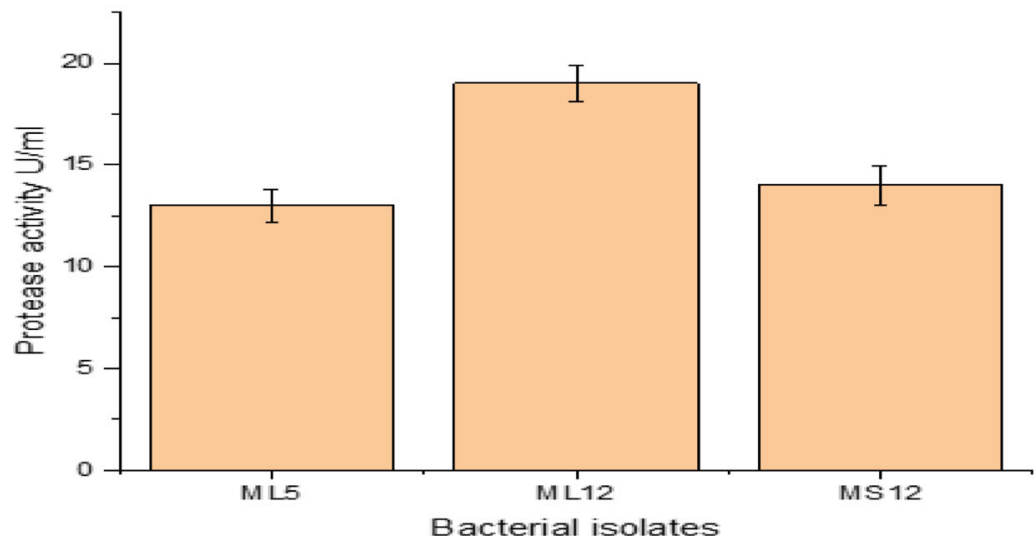

c. Alkaline Protease activities of the selected bacterial isolates

Fig. 4 a Biomass production by selected alkaline protease producing bacterial isolates. $\mathbf{b}$ Total protein concentration of the selected bacterial isolates. c Alkaline protease activities of the selected bacterial isolates 
an effective candidate for the commercial production of alkaline protease enzyme.

\section{Molecular identification}

Genomic DNA of the selected bacterial isolate ML5, ML12, and MS12 was extracted and the same was amplified by polymerase chain reaction (PCR) and visualized using agarose gel electrophoresis (Fig. 5). Further ML12 only forwards to gene sequencing. Blast result showed that ML12 was $97.86 \%$ homologous to the nucleotide of Bacillus cereus strains (MK968813.1) and 97.87\% homologous to Bacillus cereus strains (KY995152.1). A phylogenic tree was constructed as shown in Fig. 6 based on 16S rRNA gene sequences of isolate ML12 (Bacillus cereus stain - MN629232.1) and its related nucleotide sequences were used to construct the phylogenic tree using the mega x software and neighbor-joining method. Then finally, we are conformed based on our research work ML12-Bacillus cereus stain is the best alkaline protease producing bacteria, and we are using this bacteria for further media optimization and industrial application.

\section{Discussions}

Our present study reported twenty-eight isolates out of which four bacterial samples (21.4\%) are notable for their property of discharging protease enzyme as an extracellular product. On the contrary, the study (Misa et al. 2003; Chandran et al. 2014) conducted with samples collected from Antarctica, revealed successful isolation of seventy-five aerobic heterotrophy using a packed column bioreactor for the process of production of alkaline protease. Similarly, Ravishankar (2012) reported the isolation of six bacterial isolates from fish market waste soil having the ability to produce protease for commercial production. Hadush et al. (2017) isolated 147 colonies from three sampling sites, out of which 85 isolates were found to be effective for the production of protease.

The main reasons for getting a larger number of positive isolates are due to the larger sample size and the higher number of the sampling site. Results of the study conducted by Gupta et al. (2005) proved the protease production ability of Streptomycin sp. CD3 isolates. The isolated strains were subjected to primary and secondary screening for identification of protease-producing ability. Following the results of primary screening of 28 isolates, the highest clearance zone was formed by three potential alkaline protease bacteria isolates namely ML 5, ML12, and MS 12 isolates (14, 18, and $15 \mathrm{~mm}$, respectively). Similarly, the secondary screening showed a diameter of $14.00 \pm 0.75 \mathrm{~mm}, 19.50 \pm 0.66 \mathrm{~mm}$, and $15.00 \pm 1.32 \mathrm{~mm}$ for ML 5, ML12, and MS 12 revealing the highest hydrolysis zone was recorded by the isolate ML12. Bacterial morphological studies based on microscopic analysis and colony morphology are carried out as stated by Ahmad and Ansari (2013) of the three isolates revealed that all three were motile rod-shaped bacteria possessing endospores where ML5, MS12, and ML12 isolate is determined to be Gram-positive.

Colony characteristics of the three isolates, when grown on nutrient agar plates, revealed that all three isolates are smooth and opaque colonies where ML12 isolate was white and the rest of MS12 and ML5 isolates are red. Biochemical identification of the three isolates

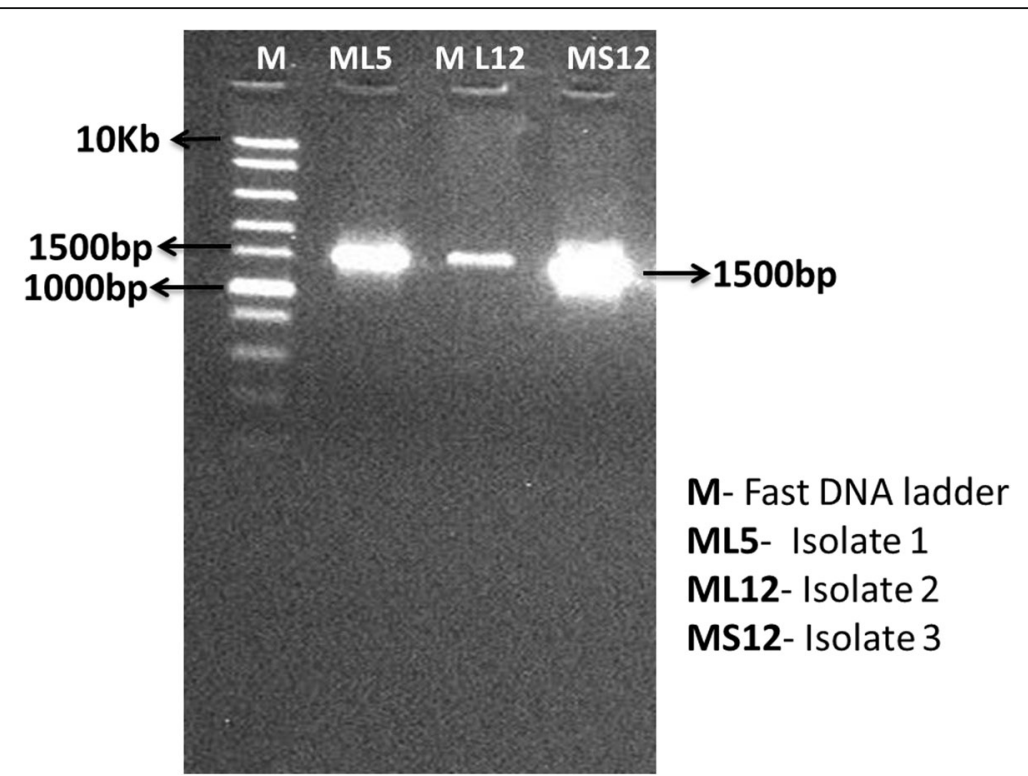

Fig. 5 PCR amplification product of bacterial Genomic DNA from selected bacterial isolates. Electrophoresis was performed on a 1.2\% Agarose gel stained with gel red 


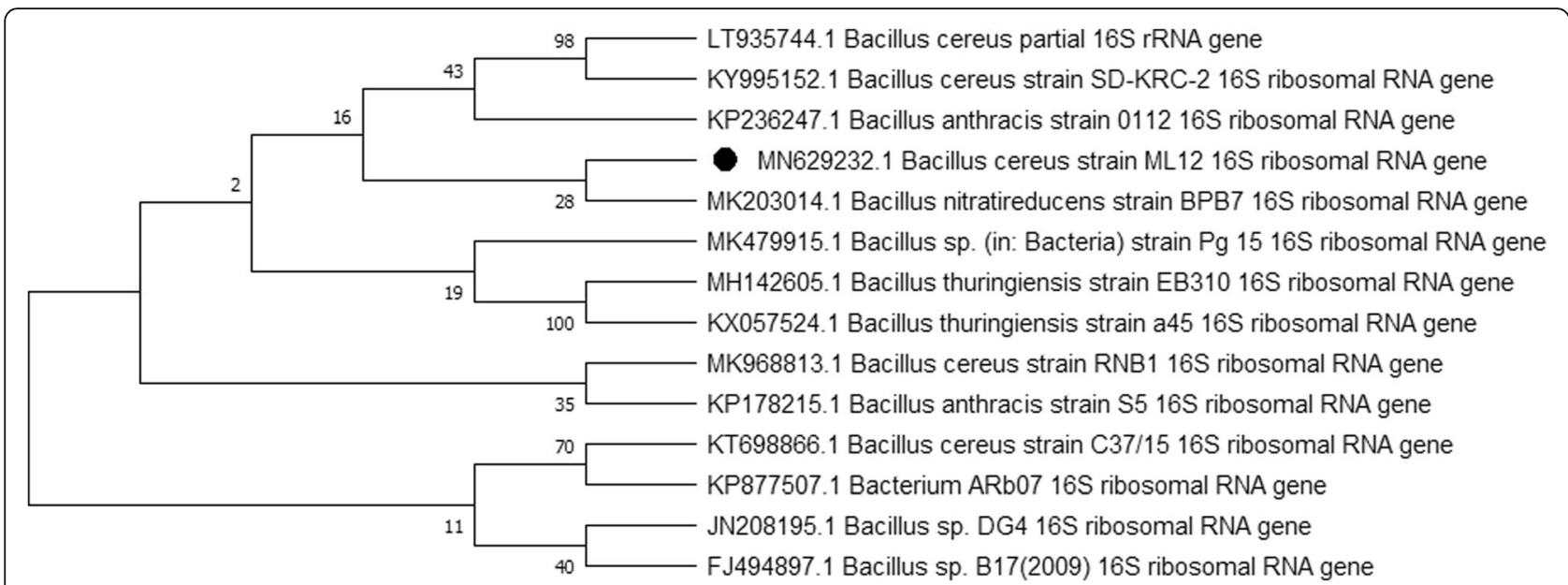

Fig. 6 The phylogenetic tree was constructed based on 16S rRNA gene sequences of Bacillus cereus (ML12) with other Bacillus species obtained from the GenBank database

was carried out as per the method prescribed by Harley and Prescott (2002), Boominadhan et al. (2009), Pandian et al. (2012), Kiran et al. (2002), Mazotto et al. (2010), and Han et al. (2012) revealed that all the three isolates hydrolyzes starch, casein, and gelatin and ferments sucrose, glucose, and galactose but not lactose. Fructose is fermented by MS12 and ML12 isolates but not ML5 and mannitol is fermented by MS12 and ML5 but not ML12. The three isolates were based on the comparison of the biochemical results with the studies (Bergey et al. 1994); all three isolates were found out to be Bacillus species.

Generally, bacterial isolates of Bacillus species are proven to be effective for the production of extracellular proteases and the same fact was proved valid upon comparing the results of the study conducted by (Alnahdi 2012; Verma et al. 2011) stating that out of the six isolates screened for protease production, two were found to be positive. Shake flask test revealed the higher biomass production ratio and alkaline protease activity of ML12 and its commercial potential for larger product recovery. Hence, ML12 isolate was considered for molecular identification, and with the aid neighborhood method, it was found out to be Bacillus cereus and also its best alkaline protease-production bacteria (Alnahdi 2012; Kumar et al. 2016).

\section{Conclusions}

The present study was focused on isolating, screening, and identification of alkaline protease-producing bacteria from leather industry effluents. The first twenty-eight different bacterial isolates were identified from the leather industry effluent. Among them, three bacterial isolates showed potent proteolytic alkaline protease activity on skim milk agar plate assay. The proteolytic bacterial isolates were then further screened for alkaline protease production using the shake flask method and isolate ML12 was observed to have a higher alkaline protease (19 IU/ml) producing potential bacteria and it's comparing with other two bacteria strain this bacterial strain is very high production and its produced novel enzyme. Based on morphological and biochemical characteristics the strain was identified as Bacillus species which was later identified as Bacillus cereus using 16S rRNA sequencing techniques. These new potential alkaline Protease bacteria are recommended for further alkaline protease research work and enzyme-based industrials.

\section{Acknowledgements}

We thank the College Dean, Head of Department, and Lab coordinator Mr. Alazar Yeshitla, Dept. of Biotechnology, College of Biological and Chemical Engineering help us with this research work.

\section{Authors' contributions}

All authors have carried out the collection of a sample from the Modjo leather industry effluent. Chandran Masi and Getachew Gemechu carried out the isolation of potential bacteria. Mesfin Tafesse and Chandran Masi carried out the identification of bacteria. All authors are contributed by the final confirmation of potential alkaline protease-producing bacteria and manuscript revisions. All authors have approved the final version of the manuscript and agree to be held accountable for the content therein.

\section{Funding}

This research work was support by the Directorate of Research and Technology Transfer, Addis Ababa Science and Technology University in funding an internal Research grant (Ref No: IBC 06/2011).

Availability of data and materials

The datasets used and/or analyzed during the current study are available from the corresponding author on reasonable request.

\section{Declarations}

Ethics approval and consent to participate Not applicable.

Consent for publication

Not applicable. 


\section{Competing interests}

The authors declare that they have no competing interests.

Received: 18 January 2021 Accepted: 30 April 2021

Published online: 06 July 2021

\section{References}

Agrahari S, Wadhwa N (2010) Degradation of chicken feather a poultry waste product by keratinolytic bacteria isolated from dumping site at ghazipur poultry processing plant. Int J Poult Sci 9(5):482-489. https://doi.org/10.3923/ ijps.2010.482.489

Ahmad J, Ansari TA (2013) Alkaline protease production using proteinaceous tannery solid waste. J Pet Environ Biotechnol 04(01). https://doi.org/10.41 72/2157-7463.1000136

Alnahdi HS (2012) Isolation and screening of extracellular proteases produced by new isolated bacillus sp. J Appl Pharm Sci 2:071-074. https://doi.org/10.7324/ JAPS.2012.2915

Bergey DH, Holt JG, Krieg NR, Sneath HA (1994) Bergey's Manual of determinative bacteriology, 9th edn. Williams Wilkins, Baltimor

Boominadhan U, Rajakumar R, Sivakumaar PKV, Joe MM (2009) Optimization of protease enzyme production using Bacillus $\mathrm{Sp}$. isolated from different wastes. Bot Res Int 2:83-87

Farrelly V, Rainey FA, Stackebrandt E (1995) Effect of genome size and rrn gene copy number on PCR amplification of 16S rRNA genes from a mixture of bacterial species. Appl Environ Microbiol 61(7):2798-2801. https://doi.org/1 0.1128/AEM.61.7.2798-2801.1995

Gupta A, Roy I, Patel RK, Singh SP, Khare SK, Gupta MN (2005) One-step purification and characterization of an alkaline protease from haloalkaliphilic Bacillus sp. J Chromatogr A 1075(1-2):103-108. https://doi.org/10.1016/j. chroma.2005.03.127

Gupta R, Beg Q, Lorenz P (2002) Bacterial alkaline proteases: molecular approaches and industrial applications. Appl Microbiol Biotechnol 59(1):1532. https://doi.org/10.1007/s00253-002-0975-y

Hadush M, Andualem B, Kebede A et al (2017) Isolation of Protease Producing Bacteria (Bacillus spp.) From Soil and Water Samples of Gondar Town, Ethiopia. Res J Pharm Biol Chem Sci 8:211-222

Han M, Luo W, Gu Q, Yu X (2012) Isolation and characterization of a keratinolytic protease from a feather-degrading bacterium Pseudomonas aeruginosa C11. Afr J Microbiol Res 6(9):2211-2221. https://doi.org/10.5897/ajmr11.921

Harley JP, Prescott LM (2002) Laboratory exercises in microbiology. 5th Ed. The McGraw- Hill companies.

Khan MA, Ahmad N, Zafar AU et al (2011) Isolation and screening of alkaline protease producing bacteria and physio-chemical characterization of the enzyme. Afr J Biotechnol 10:6203-6212. https://doi.org/10.5897/AJB11.413

Kiran KSP, Satyavani Y, Chandana Lakshmi MW, Sridevi V (2002) Production of protease enzyme using various sources: review. Res J Biotechnol 7:250-258.

Kumar S, Stecher G, Tamura K (2016) MEGA7: molecular evolutionary genetics analysis version 7.0 for bigger datasets. Mol Biol Evol 33(7):1870-1874.

Legesse DY (2017) Optimization and partial characterization of bacillus protease isolated from soil and agro-industrial wastes. Int J Nutr Food Sci 6(1):31-38. https://doi.org/10.11648/j.jinfs.20170601.16

Masi C, Vivek P, Sowmya V, Sindhuja V, Parthasarathi N (2014) Production and process optimization of protease using various bacterial species - a review. Int J ChemTech Res 6(9):4268-4275

Masi C (2020) Immobilization of Pseudomonas Aeruginosa in different matrices for the production of alkaline protease. Int J Recent Technol Eng 9(1):956-959 ISSN: 2277-3878

Masi C, Vivek P, Kotteshwari J, Mithun C, Uma Maheswaran A, Parthasarathi N (2015) Cloning, expression and characterization of serine proteasegene from Entrococcus hirae. BioTechnol : Indian J 11(9):328-334

Masi C, Chandramohan C, Ahmed MF (2017a) Immobilization of the magnetic nanoparticles with alkaline protease enzyme produced by enterococcus hirae and pseudomonas aeruginosa isolated from dairy effluents. Brazilian Arch Biol Technol 60. https://doi.org/10.1590/1678-4324-2017160572

Masi C, Naveen Kumar KR, Gowtham Raja NC, Umesh R (2017b) Immobilization of alkaline protease enzyme from pseudomonas aeruginosaon surface functionalized magnetic iron oxide nanoparticles. Res J Pharmaceut, Biol Chem Sci 8(16):153-161

Masi C, Fazil Ahmed M, Parthasarathi N (2014) A comparative study on the protease producing bacteria isolated from dairy effluents of Chennai region, identification, characterization and application of enzyme in detergent formulation, asian journal of microbiology. Biotechnol Environ Sci 16(1):41-46

Mazotto AM, Lage Cedrola SM, Lins U, Rosado AS, Silva KT, Chaves JQ, Rabinovitch L, Zingali RB, Vermelho AB (2010) Keratinolytic activity of Bacillus subtilis AMR using human hair. Lett Appl Microbiol 50(1):89-96. https://doi. org/10.1111/j.1472-765X.2009.02760.x

Pandian S, Sundaram J, Panchatcharam P (2012) Isolation, identification and characterization of feather degrading bacteria. Eur J Exp Biol 2:274-282

Pires-Cabral P, da Fonseca MMR, Ferreira-Dias S (2010) Esterification activity and operational stability of Candida rugosa lipase immobilized in polyurethane foams in the production of ethyl butyrate. Biochem Eng J 48(2):246-252. https://doi.org/10.1016/j.bej.2009.10.021

Ravishankar K (2012) Isolation of alkaline protease from Bacillus subtilis AKRS3. Afr J Biotechnol 11(69):13415-13427. https://doi.org/10.5897/ajb12.404

Reda AH (2016) Physico-chemical characterization of tannery effluent and its impact on the nearby river. J Environ Chem Ecotoxicol 8(6):44-50. https://doi. org/10.5897/jece2015.0365

Reysenbach A-L, Pace NR, Robb FT, Place AR (1995) Archaea: a laboratory manual-thermophiles. CSHLP Protoc 16:101-107.

Saha RN, Wissink EM, Bailey ER, Zhao M, Fargo DC, Hwang JY, Daigle KR, Fenn JD, Adelman K, Dudek SM (2011) Rapid activity-induced transcription of Arc and other IEGs relies on poised RNA polymerase II. Nat Neurosci 14(7):848-856. https://doi.org/10.1038/nn.2839

Sharma K (2007) Manual of microbiology; tools \& techniques, 2nd edition. Ane Books Pvt., Ltd. ISBN 10:8180520889.

Sharmin S, Towhid Hossain M, Anwar MN (2005) Isolation and characterization of a protease producing bacteria bacillus amovivorus and optimization of some factors of culture conditions for protease production. J Biol Sci 5(3):358-362.

Sneha S, Das MP, Jeyanthi Rebecca L (2014) Isolation and screening of protease producing bacteria from marine waste. J Chem Pharm Res 6:1157-1159.

Tiwari ON, Devi TB, Devi KS et al (2015) Isolation and optimization of alkaline protease producing Bacteria from undisturbed soil of NE-region of India falling under Indo-Burma biodiversity hotspots. J Appl Biol Biotechnol 3:2531. https://doi.org/10.7324/jabb.2015.3406

Verma A, Pal HS, Singh R, Agarwal S (2011) Potential of alkaline protease isolated from Thermoactinomyces sp. RM4 as an alternative to conventional chemicals in leather industry dehairing process. Int J Agric Environ Biotechnol 4:173-178.

Wery N, Gerike U, Sharman A, Chaudhuri JB, Hough DW, Danson MJ (2003) Use of a packed-column bioreactor for isolation of diverse protease-producing bacteria from antarctic soil. Appl Environ Microbiol 69:1457-1464. https://doi. org/10.1128/AEM.69.3.1457-1464.2003

Yucel Y (2012) Optimization of immobilization conditions of Thermomyces lanuginosus lipase on olive pomace powder using response surface methodology. Biocatal Agric Biotechnol 1(1):39-44. https://doi.org/10.1016/j. bcab.2011.08.009

\section{Publisher's Note}

Springer Nature remains neutral with regard to jurisdictional claims in published maps and institutional affiliations.

\section{Ready to submit your research? Choose BMC and benefit from:}

- fast, convenient online submission

- thorough peer review by experienced researchers in your field

- rapid publication on acceptance

- support for research data, including large and complex data types

- gold Open Access which fosters wider collaboration and increased citations

- maximum visibility for your research: over $100 \mathrm{M}$ website views per year

At BMC, research is always in progress.

Learn more biomedcentral.com/submissions 